\title{
PERAN MAJELIS PENGAWAS DAN KEHORMATAN TERHADAP NOTARIS YANG MEMBUAT AKTA PERJANJIAN NOMINEE
}

\author{
Anak Agung Bagus Maha Wikantha \\ Program Magister Kenotariatan Fakultas Hukum Universitas Brawijaya \\ JI. MT. Haryono No 169; Malang; 65145; Indonesia; (0341) 553898 \\ mahawikantha@yahoo.com
}

\begin{abstract}
The Notary Supervisory Council and the Notary Public Honor Council (MKN) have not optimally conducted supervision and guidance on notaries in Indonesia. Supervision and guidance only form of sanction is also given uncertain of both institutions to the notary who violates the code of notary ethics related to the making of the nominee agreement. This research analyzes the role of Supervisory Board of Notary and Honorary Board of Notary as well as the form of sanction given to Notary which make deed of nominee agreement. The research method is empirical juridical. The results of the research, MPN's roles held a hearing to examine notaries and administer administrative sanctions. The role of MKN in solving the case of violation of code of ethics of Notary to Notary which makes nominee agreement very limited, because MKN can only conduct examination. The role of MKN only gives approval or rejection of Notary's invitation to its presence in the judicial system process. Against a Notary who makes a nominee agreement imposed with civil sanctions, the administration may also be subject to criminal sanctions. The responsibility of a notary is criminally imposed if a notary performs a deed like a fake signature.
\end{abstract}

Keywords: Assembly of Supervisors, Honorary Council, Nominee Agreement.

\begin{abstract}
Abstrak
Majelis Pengawas Notaris dan Majelis Kehormatan Notaris (MKN) belum melakukannya secara optimal melaksanakan pengawasan dan pembinaan terhadap notaris di Indonesia. Pengawasan dan pembinaan tersebut, bentuk sanksi yang diberikan juga masih belum pasti dari kedua lembaga ini terhadap notaries yang melakukan pelanggaran kode etik notaris terkait pembuatan akta perjanjian nominee. Penelitian ini akan menganalisis peran Majelis Pengawas Notaris dan Majelis Kehormatan Notaris serta bentuk sanksi yang diberikan terhadap Notaris yang membuat akta perjanjian nominee. Metode penelitian adalah yuridis empiris. Hasil penelitian, Peran MPN menyelenggarakan sidang untuk memeriksa Notaris dan pemberian sanksi administratif. Peran MKN dalam hal penyelesaian kasus pelanggaran kode etik Notaris terhadap Notaris yang membuat perjanjian nominee sangat terbatas, karena MKN hanya dapat melakukan pemeriksaan. Peran MKN hanya memberikan persetujuan atau penolakan terhadap pemanggilan Notaris atas kehadirannya dalam proses sistem peradilan. Terhadap Notaris yang membuat perjanjian nominee dijatuhi sanksi perdata, administrasi juga dapat dijatuhi sanksi pidana. Tanggung jawab notaris secara pidana dikenakan apabila notaris melakukan perbuatan seperti pemalsuan tanda tangan.
\end{abstract}

Kata kunci: Majelis Pengawas, Majelis Kehormatan, Perjanjian Nominee. 


\section{Pendahuluan}

Perjanjian nominee adalah suatu perjanjian antara para pihak yang berdasarkan aturan hukum dilarang untuk dapat menjadi subyek hukum yang memegang hak milik atas tanah. Dalam situasi ini, yakni Warga Negara Asing (selanjutnya disebut WNA) yang meminjam namanya dengan Warga Negara Indonesia (selanjutnya disebut WNI), dengan maksud agar WNA itu bisa memiliki atau menguasai tanah atas hak milik secara nyata (de facto), namun secara hukum atau legal-formal (de jure) tanah hak milik tersebut diatas namakan WNI. Dengan kata lain, WNI tersebut "dipinjam" namanya oleh WNA tersebut (Maria, 2012). Banyak WNA yang menguasai tanah hak milik WNI sendiri, yang dilakukan melalui pembuatan perjanjian nominee dan dilaksanakan di hadapan Notaris.

Praktek pembuatan perjanjian nominee ini, secara jelas telah melanggar asas nasionalisme yang ada dalam hukum agraria di Indonesia, yaitu hanya WNI yang boleh mempunyai hak milik di Negara Indonesia. Pemindahan hak milik kepada WNA dilarang dengan ancaman akta tanah atau bangunan yang diterbitkan batal demi hukum dan jatuh pada Negara. Penyelesaian kasus penyelundupan hukum yang dilakukan dengan praktek pembuatan perjanjian nominee secara notariil ini, diperlukan peran oleh lembaga Notaris.

Peran lembaga Notaris sangat dibutuhkan agar permasalahan tersebut tidak terus terjadi. Ada 2 (dua) lembaga yang bertugas dan memiliki wewenang untuk melakukan fungsi pengawasan dan pembinaan pada profesi Notaris, yaitu Majelis Pengawas Notaris (selanjutnya disebut MPN) dan Majelis Kehormatan Notaris (selanjutnya disebut (MKN). Notaris adalah pejabat umum yang secara profesi diangkat oleh Menteri Hukum dan Hak Asasi Manusia (Menkumham) dan mendapat kewenangan secara atributif berdasarkan undangundang dan bekerja untuk kepentingan masyarakat, bangsa dan negara (Wisnuwardhani, 2017). Pengawasan terhadap Notaris dilakukan oleh
MPN, yaitu, untuk mengawasi ketaatan dan kepatuhan Notaris dalam menjalankan UUJN. Sedangkan, MKN adalah untuk melakukan pembinaan terhadap Notaris terkait pelaksanaan tugas jabatannya serta memberikan persetujuan atau tidak terhadap pemeriksaan yang akan dilakukan oleh penyidik.

Kedua lembaga ini, mempunyai tujuan untuk melakukan pembinaan dan menjaga keseluruhan martabat dan jabatan Notaris. Adapun untuk mewujudkan tujuan ini, MPN mempunyai kewenangan yang diatur di dalam UUJN dan UUJN-P, sedangkan MKN mempunyai tugas dan fungsi yang diatur di dalam Peraturan Menteri Hukum dan Hak Asasi Manusia Republik Indonesia Nomor 7 tahun 2016 tentang Majelis Kehormatan Notaris.

Kewenangan, tugas dan fungsinya, MPN dan MKN belum melakukannya secara optimal, yaitu, mengenai peran kedua lembaga ini untuk melakukan tugas dan fungsinya sebagai pengawas dan pembina Notaris yang terkait dengan penyelundupan hukum dalam hal pembuatan akta perjanjian nominee. Bentuk sanksi yang diberikan juga masih belum pasti dari kedua lembaga ini, terhadap Notaris yang melakukan pelanggaran terhadap ketentuan yang terdapat dalam kode etik Notaris terkait pembuatan akta perjanjian nominee, sehingga masih ada Notaris yang melakukan pelanggaran terhadap ketentuan yang terdapat dalam kode etik Notaris dengan cara penyelundupan hukum melalui pembuatan akta perjanjian nominee. Praktek perjanjian nominee Di Provinsi Bali khususnya di Kota Denpasar, antara WNI dengan WNA yang menyalahi aturan Kode Etik Notaris serta UUJN tersebut masih terus terjadi.

Berdasarkan uraian yang telah dipaparkan dalam latar belakang tersebut diatas, maka ruang lingkup permasalahan yang penulis rumuskan, meliputi peran Majelis Pengawas Notaris dan Majelis Kehormatan Notaris dalam penyelesaian kasus pelanggaran kode etik notaris terhadap no- 
taris yang membuat akta perjanjian nominee dan bentuk sanksi yang diberikan oleh, Majelis Pengawas Notaris dan Majelis Kehormatan Notaris terhadap notaries yang membuat akta perjanjian nominee.

\section{Metode Penelitian}

Berdasarkan perumusan masalah dan tujuan penulisan yang telah penulis uraikan di atas, maka metode penelitian yang digunakan adalah yuridis empiris. Penelitian hukum empiris yaitu dengan cara melakukan kajian secara dua arah antara hukum dengan keberadaan lembaga MPN dan MKN dalam mengkaji norma-norma dan aturanaturan hukum yang berlaku di masyarakat, selain itu metode ini juga mengkaji ketentuan hukum yang berlaku serta apa yang terjadi dalam kenyataannya di masyarakat (Bambang, 2002). Penelitian ini menggunakan pendekatan yuridis sosiologis. Pendekatan yang dilakukan terhadap kondisi nyata di masyarakat yaitu tentang notaris yang membuat akta perjanjian nominee dengan maksud dan tujuan untuk mencari dana menemukan fakta (fact-finding), lalu melakukan proses identifikasi terhadap suatu permasalahan (problem-identification) dan berakhir pada proses penyelesaian masalah (problem-solution) terkait dengan peran dan bentuk sanksi yang diberikan oleh MPN dan MKN terhadap Notaris yang membuat akta perjanjian nominee (Soejono, 1982).

Penelitian ini menggunakan jenis data primer, data sekunder dan data tersier,yang terdiri dari Data Primer, sumber dari data primer didapat dengan cara meneliti secara langsung untuk terjun ke lapangan yang meliputi data, informasi dan keterangan hasil wawancara dengan pihak-pihak berkaitan langsung dengan permasalahan. Sementara data sekunder dalam penelitian ini adalah peraturan perundang-undangan yaitu Undang-Undang Dasar Negara Republik Indonesia Tahun 1945, Kitab Undang-Undang Hukum Perdata (KUHPerdata), Undang-Undang Pokok
Agraria Nomor 5 Tahun 1960 tentang Peraturan Dasar Pokok-Pokok Agraria, Undang-Undang Nomor 30 Tahun 1999 tentang Arbitrase dan Alternatif Penyelesaian Sengketa, Undang-Undang Nomor 30 Tahun 2004 tentang Jabatan Notaris, Undang-Undang Republik Indonesia Nomor 2 Tahun 2014 tentang Perubahan Atas UndangUndang Nomor 30 tahun 2004 tentang Jabatan Notaris, Peraturan Menteri Hukum dan Hak Asasi Manusia Republik Indonesia Nomor 7 tahun 2016 tentang Majelis Kehormatan Notaris. Data tersier pada penelitian ini merupakan data yang mendukung data primer dan sekunder, seperti ensiklopedia, internet dan sebagainya.

\section{Hasil dan Pembahasan}

\section{A. Peran Majelis Pengawas dan Kehormatan Notaris Dalam Penyelesaian Kasus Pelang- garan Kode Etik Notaris terhadap Notaris Yang Membuat Akta Perjanjian Nominee}

Permasalahan kasus mengenai penyelundupan hukum dan pelanggaran kode etik notaris dalam pembuatan akta perjanjian nominee oleh Notaris di Kota Denpasar yang diangkat dalam penelitian ini ada 2, yaitu pada tahun 2014 dan 2015 adalah sebagai berikut:

1. Kasus pertama pada tahun 2014, Putusan No.787/Pdt.G/2014/PN.DPS

Karpika Wati (Penggugat) sebagai WNI (nominee) menggugat Alain Maurice Pons (Tergugat I) sebagai WNA, dan Notaris bernama Eddy Nyoman Winarta, SH (TergugatII) yang berkantor di Kabupaten Badung. Penggugat pada tanggal 12 Juni 2007 telah membeli sebidang tanah sesuai dengan Setipikat Hak Milik Nomor: 1022/Desa Pererenan, dengan Nomor Identifikasi Bidang Tanah: 22.03.05.18.0113, dengan Surat Ukur Nomor: 1216/Pererenan/2008, tertanggal 12 Maret 2008 , seluas $975 \mathrm{~m} 2$ (sembilan ratus tujuh puluh lima meter persegi) yang terletak di Jalan Jantuk Angsa (dahulu bernama Gang Sabana), 
Desa Pererenan, Kecamatan Mangwi, Kabupaten Badung, Propinsi Bali tercatat atas nama KW (Penggugat) berdasarkan Akta Jual Beli Nomor: 169 tertanggal 12 Juni 2007 yang telah dibuat dan ditandatangani di Kantor Notaris dan PPAT Kabupaten Badung, ENW (Tergugat II) yang beralamat di Komplek Pertokoan Segitiga Emas Kav. 31-32, Jalan By Pass Ngurah Rai Nomor 5, Kuta, Kabupaten Badung, Propinsi Bali, yang kemudian pada awal tahun 2008 tanah tersebut telah dibangun sebuah villa dengan nama EMMANUELLE yang ditempati oleh penggugat sendiri hingga saat ini.

Penggugat dan Tergugat I telah saling mengenal dengan baik sejak tahun 2006. Dengan bujuk rayu dan iming-iming janji bahwa tanah yang dibeli Penggugat tersebut akan segera dibangun Villa dan akan disewakan kepada pihak lain yang kemudian hasil yang didapat dari pengelolaan Villa tersebut akan dibagi bersama, Tergugat I kemudian meminta Penggugat untuk membuatkan akta-akta atas tanah tersebut dihadapan Tergugat II, adapun AktaAkta Notaris tersebut adalah sebagai berikut:

“a) Akta Notaris Nomor 89 tanggal 24 Maret 2008 tentang Sewa Menyewa Tanah antara Penggugat selaku Pihak Pertama yang Menyewakan dan Tergugat I selaku Pihak Kedua sebagai Pihak Penyewa;

b) Akta Notaris Nomor 90 tanggal 24 Maret 2008 tentang Pengakuan Hutang dengan Memakai Jaminan antara Tergugat I selaku Pihak Pertama yang menghutangkan dan Penggugat selaku Pihak Kedua sebagai Pihak yang Berhutang;

c) Akta Notaris Nomor 91 tanggal 24 Maret 2008 tentang Pernyataan dan Kuasa antara Penggugat selaku yang menyatakan dan Pemberi Kuasa dan Tergugat I selaku yang menerima Pernyataan dan Penerima Kuasa;

d) Akta Notaris Nomor 108 tanggal 1 April 2008 tentang Akta Pemberian Hak Tanggungan
(APHT) atas nama Alain Maurice Pons, selaku Tergugat I, yang beralamat di 10, rue Jean Vidaihet 31800 St. Gaudens, France." Obyek tanah tersebut di atas yang dibuatkan dan dibebani dengan Akta-akta yang dibuat dihadapan Notaris sangat jelas memposisikan Penggugat selaku nominee.

2. Kasus kedua pada tahun 2015, No.158/Pdt.G/ 2015/PN.DPS

ST sebagai penggugat, dengan Notaris berinisial ESP, SH sebagai Tergugat yang berkantor di Kabupaten Badung. Sebelum kasus ini terjadi, MS (WNI) merupakan nominee dari AF (WNA) sebagai pemilik tanah dengan SHM: 10832/Kelurahan Kerobokan. Selanjutnya ada perjanjian Villa Banteng No.39 (Villa Banteng Agreement No: 39), yaitu antara MR (WNA) sebagai pihak pertama dan MS (WNI) sebagai pihak kedua dengan Hak Pakai Nomor 36/Kerobokan untuk Villa Banteng Atas (VBA).

ST (WNI) dan MR (WNA) merupakan sepasang suami istri. MR (WNA) menghibahkan Villa Banteng Atas (VBA) kepada istrinya yaitu ST menjadi Hak Milik. Selanjutnya, Villa Banteng Bawah (VBB) dibeli oleh DL (WNA) dan nominee tetap pada MS (WNI). Jual beli dan pembuatan perjanjian nominee ini dilakukan di hadapan Notaris ESP,SH. Pada tahun 2014, IMB ST belum terbit, namun IMB dari DL telah terbit. Di sinilah sengketa antara para pihak mulai terjadi. Ternyata ada pemalsuan tanda tangan oleh Notaris ESP,SH saat mengurus ijin IMB yang seharusnya ditandatangani oleh ST. Jadi, atas dasar pemalsuan tanda tangan inilah ST mengajukan gugatan terhadap Notaris ESP, $\mathrm{SH}$ ke Pengadilan Negeri Denpasar dengan Nomor 158/Pdt.G/2015/PN.DPS.

Berdasarkan 2 (dua) kasus tersebut di atas, Bapak Notaris Ketut Wirata mengatakan:

"Perjanjian nominee ini melanggar nasionalisme sama penyelundupan hukum juga dan baru akan 
ketahuan, jika ada sengketa dari para pihak atau Notarisnya. Kalau tidak ada sengketa ya, Notarisnya aman-aman saja. Memang aman-aman saja untuk sekarang, tapi untuk nanti belum tentu, karena ada kasus yang menunggu. Maka dari itu, saya tidak mau membuat perjanjian nominee."

Perjanjian nominee yang terdapat dalam kasus pertama Putusan No.787/Pdt.G/2014/PN.DPS dan kedua Nomor 158/Pdt.G/2015/PN.DPS. tersebut di atas adalah termasuk dalam kategori penyelundupan hukum karena perjanjian nominee secara yuridis formal tidak menyalahi aturan, namun terdapat aturan yang jelas di dalam pasal 26 ayat (2) UUPA yang menyatakan bahwa:

"Setiap jual beli, penukaran, penghibahan, pemberian dengan wasiat dan perbuatan-perbuatan lain yang dimaksudkan untuk langsung atau tidak langsung memindahkan hak milik kepada orang asing, kepada seorang warga negara yang di samping kewarganegaraan Indonesianya mempunyai kewarga negaraan asing atau kepada suatu badan hukum, kecuali yang ditetapkan pasal 21 ayat (2), adalah batal karena hukum dan tanahnya jatuh kepada negara, dengan ketentuan, bahwa hak-hak pihak lain yang membebaninya tetap berlangsung serta semua pembayaran yang telah diterima oleh pemilik tidak dapat dituntut kembali."

Ada beberapa faktor yang mendasari para pihak dan Notaris untuk membuat perjanjian nominee. Dalam hal ini, Ibu Notaris Nella Hasibuan mengatakan:

"Faktor-faktor yang mendasari para pihak untuk membuat perjanjian nominee, yaitu:

a) Dari pihak Notaris, Notaris tersebut kurang paham akan hukum pertanahan di Indonesia yang terkait dengan perjanjian nominee yaitu pasal 26 ayat (2) dan hanya melihat dari sisi pandang hukum perjanjian KUHPer saja, yaitu asas kebebasan berkontrak dan kesepakatan para pihak. b) Dari pihak WNI, WNI tersebut juga kurang paham dan mendapat keuntungan dari pembuatan akta perjanjian nominee dengan pembagian keuntungan.

c) Dari pihak WNA, WNA tersebut juga samasama kurang paham dan ingin memiliki seumur hidup dari tanah tersebut karena takut hak atas tanahnya hilang. WNA hanya ingin secure saja untuk berinvestasi di Indonesia.

Jadi, pada awalnya para pihak tidak ada yang ingin untukniat buruk, walaupun ada beberapa yang paham namun terus untuk dilanjutkan pembuatan perjanjian nominee."

Menurut Pasal 26 ayat (2) UUPA, Hak Milik kepada WNA dilarang dan pelanggaran terhadap pasal ini akan mengakibatkan perjanjian tersebut batal demi hukum. Salah satu akta yang disebut melanggar hukum adalah Akta Antidateren, dimana substansi akta tidak sesuai dengan fakta. Contohnya Akta Pernyataan WNI terhadap WNA dalam jual beli tanah, dimana WNA adalah pihak tidak diperbolehkan memiliki hak atas tanah (Andi, 2010).

\section{B. Peran Majelis Pengawas Notaris Dalam Penyelesaian Kasus Pelanggaran Kode Etik Notaris Terhadap Notaris yang Membuat Akta Perjanjian Nominee}

Sesuai dengan UUJN-P tentang Jabatan Notaris, Majelis Pengawas Notaris mengawasi perilaku dan jabatan Notaris. Majelis Pengawas Notaris juga memiliki kewenangan menggelar sidang untuk memeriksa dugaan adanya pelanggaran UUJN dan kode etik Notaris, dalam hal ini terhadap Notaris yang membuat perjanjian nominee.Notaris Ketut Wirata, mengatakan:

"Majelis Pengawas Notaris adalah badan yang mempunyai kewenangan dan kewajiban untuk melakukan pembinaan dan pengawasan terhadap Notaris serta akta yang dibuat oleh Notaris." 
Majelis Pengawas dibentuk oleh Menteri Hukum dan Hak Asasi Manusia Republik Indonesia dengan cara "pendelegasian" dalam tugas dan fungsi pengawasan dan pembinaan jabatan Notaris, sebagaimana disebutkan dalam Pasal 67 UUJN juncto Pasal 1 ayat 1 Peraturan Menteri Hukum dan Hak Asasi Manusia Republik Indonesia Nomor M.02.PR.08.10 Tahun 2004.

Dalam melaksanakan tugas kewajibannya, Majelis Pengawas secara fungsional terbagi menjadi 3 hierarki administratif yaitu Majelis Pengawas Daerah, Majelis Pengawas Wilayah dan Majelis Pengawas Pusat (Pasal 68 UUJN).

Peran Majelis Pengawas Notaris dalam hal penyelesaian kasus pelanggaran kode etik notaris terhadap Notaris yang membuat akta perjanjian nominee di Kota Denpasar, yaitu:"

a. Majelis Pengawas Daerah:

1. Menyelenggarakan suatu sidang yang bertujuan untuk melakukan pemeriksaan dari adanya dugaan pelanggaran Kode Etik Notaris atau pelanggaran pelaksanaan jabatan Notaris yang membuat akta perjanjian nominee;

2. Membuat dan menyampaikan laporan kepada Majelis Pengawas Wilayah;

b. Majelis Pengawas Wilayah:

1. Menyelenggarakan suatu sidang yang bertujuan untuk memeriksa dan mengambil keputusan atas laporan terkait dengan pelanggaran jabatan dan kode etik notaris;

2. Memanggil Notaris terlapor untuk dilakukan pemeriksaan atas laporan dari Majelis Pengawas Daerah;

3. Memberikan sanksi baik peringatan lisan maupun peringatan tertulis;

4. Mengusulkan pemberian sanksi terhadap Notaris kepada Majelis Pengawas Pusat berupa:

1) Pemberhentian sementara 3 (tiga) bulan sampai dengan 6 (enam) bulan; atau

2) Pemberhentian dengan tidak hormat."
C. Peran Majelis Kehormatan Notaris Dalam Penyelesaian Kasus Pelanggaran Kode Etik Notaris Terhadap Notaris Yang Membuat Akta Perjanjian Nominee

MKN mempunyai tugas dan fungsi yang diatur di dalam Pasal 18 ayat (1) dan (2) Peraturan Menteri Hukum dan Hak Asasi Manusia Republik Indonesia Nomor 7 tahun 2016 tentang Majelis Kehormatan Notaris, yaitu:"

(1). Majelis Kehormatan Notaris Wilayah mempunyai tugas:

a. Melakukan pemeriksaan terhadap permohonan yang diajukan oleh penyidik, penuntut umum, dan hakim; dan

b. Memberikan persetujuan atau penolakan terhadap permintaan persetujuan pemanggilan Notaris untuk hadir dalam penyidikan, penuntutan, dan proses peradilan.

(2). Dalam melaksanakan tugas sebagaimana disebutkan pada ayat (1), Majelis Kehormatan Notaris Wilayah mempunyai fungsi melakukan pembinaan dalam rangka:

a. Menjaga martabat dan kehormatan Notaris dalam menjalankan profesi jabatannya; dan

b. Memberikan perlindungan kepada Notaris terkait dengan kewajiban Notaris untuk merahasiakan isi Akta."

Ketua MKNW dalam menjalankan tugasnya untuk melakukan pembinaan terhadap Notaris, membentuk majelis pemeriksa yang bersifat ad hooc, yaitu untuk suatu hal yang bersifat khusus. Majelis pemeriksa beranggotakan 3 (tiga) orang yang terdiri dari setiap unsur anggota MKNW. Majelis pemeriksa terdiri dari:

a. Ketua yang merangkap sebagai anggota, yang berjumlah 1 (satu) orang; dan

b. Anggota, yang berjumlah 2 (dua) orang. Majelis Pemeriksa, dalam melakukan kegiatan pemeriksaan, dibantu oleh 1 (satu) orang sekretaris. Majelis pemeriksa memiliki wewenang untuk memeriksa dan memberikan penolakan 
atau persetujuan atas permintaan penegak hukum terkait pengambilan surat-surat atau berkas-berkas yang dilekatkan pada minuta akta dan fotokopi minuta akta dan/atau protokol Notaris dalam tempat penyimpanan Notaris serta saat proses pemanggilan Notaris. Setiap hasil dari pemeriksaan yang dilakukan oleh Majelis Pemeriksa, selanjutnya dibuatkan laporan kepada Ketua MKNW. Setelah itu, Ketua MKNW wajib untuk membuat laporan dan mengirim laporan tersebut setiap bulannya kepada Ketua MKNP.

Dalam hal pemanggilan Notaris diatur lebih lanjut Pasal 23, yaitu:"

(1) Permohonan persetujuan pengambilan minuta akta atau protokol Notaris dan pemanggilan Notaris oleh pihak penyidik, penuntut umum, atau hakim untuk hadir dalam pemeriksaan yang terkait dengan akta atau protokol Notaris yang berada dalam penyimpanan Notaris diajukan kepada Ketua Majelis Kehormatan Notaris Wilayah sesuai dengan wilayah kerja Notaris yang bersangkutan.

(2) Permohonan sebagaimana dimaksud pada ayat (1) disampaikan secara tertulis dalam bahasa Indonesia dan tembusannya disampaikan kepada Notaris yang bersangkutan.

(3) Permohonan sebagaimana dimaksud pada ayat (2) harus memuat paling sedikit:

a. nama Notaris;

b. alamat kantor Notaris;

c. nomor akta dan/atau surat yang dilekatkan pada minuta akta atau protokol Notaris dalam penyimpanan Notaris; dan d. pokok perkara yang disangkakan.

(4) Ketua Majelis Kehormatan Notaris Wilayah wajib memberikan jawaban berupa persetujuan atau penolakan terhadap permohonan sebagaimana dimaksud pada ayat (1) dalam jangka waktu paling lama 30 (tiga puluh) hari kerja terhitung sejak tanggal diterimanya permohonan.
(5) Apabila dalam jangka waktu sebagaimana dimaksud pada ayat (4) terlampaui, dianggap Majelis Kehormatan Notaris Wilayah menerima permintaan persetujuan."

Terhadap kasus yang terjadi di kota Denpasar yaitu, dalam pembuatan akta perjanjian nominee oleh Notaris. Sekretaris Majelis Kehormatan Notaris Wilayah Kota Denpasar, Bapak Ida Bagus Made Danu Kresnawan, mengatakan:

"Sepanjang tidak ada sengketa atau dipermasalahkan, MKN tidak bisa menindaklanjuti perjanjian nominee itu. MKN juga tidak bisa memantau karena itu bersifat rahasia, kecuali apabila ada gugatan ke Pengadilan, selanjutnya Notaris tersebut bisa dikenakan sanksi kode etik."

Peran MKN dalam hal penyelesaian kasus pelanggaran kode etik Notaris terhadap Notaris yang membuat perjanjian nominee sangat terbatas, karena sesuai dengan UUJNP Pasal Pasal 18 ayat (1) dan (2) Peraturan Menteri Hukum dan Hak Asasi Manusia Republik Indonesia Nomor 7 tahun 2016 tentang Majelis Kehormatan Notaris menyatakan bahwa "MKN hanya dapat melakukan pemeriksaan terhadap permohonan yang diajukan oleh penyidik, penuntut umum, dan hakim; serta memberikan persetujuan atau penolakan terhadap permintaan persetujuan pemanggilan Notaris untuk hadir dalam penyidikan, penuntutan, dan proses peradilan."

\section{Sanksi Yang Diberikan oleh Majelis Pengawas dan Kehormatan Notaris Dalam Penyelesaian Kasus Pelanggaran Kode Etik Notaris Terhadap Notaris yang Membuat Akta Perjanjian Nominee}

Perbuatan melawan hukum dalam pembuatan akta autentik yang dilakukan oleh Notaris seperti dalam pembuatan akta perjanjian nominee juga menyebabkan seorang Notaris dijatuhi sanksi. Sekretaris Majelis Kehormatan Notaris Wilayah Kota Denpasar, Bapak Ida Bagus Made Danu Kresnawan, mengatakan: 
"Sanksi terhadap Notaris yang melanggar kode etik notaris seperti pembuatan akta perjanjian nominee itu ada sanksi administrasi, perdata, pidana."

Sanksi terhadap Notaris menunjukkan Notaris tidaklah kebal terhadap hukum. Notaris yang membuat perjanjian nominee dapat dijatuhi sanksi perdata, administrasi juga dapat dijatuhi sanksi pidana. Sanksi tersebut tersebut justru mampu menjaga martabat lembaga Notaris, sebagai lembaga kepercayaan, karena pelanggaran Notaris dapat menurunkan kepercayaan masyarakat pada profesi tersebut.

a. Sanksi Administrasi

Terdapat 5 jenis sanksi administrasi berdasarkan UUJN-P apabila seorang notaris melanggar ketentuan UUJN-P seperti dalam pembuatan akta perjanjian nominee, yaitu peringatan lisan, peringatan tertulis, pemberhentian sementara, pemberhentian dengan hormat dan pemberhentian dengan tidak hormat. Sanksi-sanksi itu berlaku secara berjenjang dari yang ringan yaitu teguran lisan sampai dengan pemberhentian dengan tidak hormat. Ibu Notaris Nella Hasibuan, mengatakan "Selama yang saya amati, Notaris yang terkena kasus perjanjian nominee itu dikenakan sanksi berupa teguran baik lisan maupun tertulis."

Prosedur penjatuhan sanksi administratif dilakukan secara langsung oleh Majelis Pengawas Notaris Wilayah Kota Denpasar yang berfungsi sebagai langkah preventif (pengawasan) dan langkah represif (penerapan sanksi). Langkah preventif dilakukan melalui pemeriksaan protokol notaris secara berkala dan pencegahan pelanggaran dalam pelaksanaan jabatan notaris. Langkah represif dilakukan melalui penjatuhan sanksi oleh Majelis Pengawas Wilayah Kota Denpasar, berupa teguran lisan dan teguran tertulis serta pengusulan kepada Majelis Pengawas Pusat tentang pemberhentian sementara 3 (tiga) bulan sampai de- ngan 6 (enam) bulan dan pemberhentian tidak hormat. Sekretaris Majelis Kehormatan Notaris Wilayah Kota Denpasar, Bapak Ida Bagus Made Danu Kresnawan, mengatakan bahwa "Notaris yang membuat perjanjian nominee, bisa dikenakan sanksi pemberhentian sementara".

Kedudukan sanksi berupa pemberhentian sementara dari jabatan notaris atau skorsing dilaksanakan dalam rangka masa menunggu pelaksanaan sanksi paksaan dari Kementerian Hukum dan Hak Asasi Manusia. Sanksi pemberhentian sementara notaris dari jabatannya, bertujuan agar Notaris tidak melaksanakan tugas dan jabatannya untuk sementara waktu, sampai sanksi pemberhentian dijatuhkan. Pemberian sanksi pemberhentian sementara ini bisa berakhir dalam dua bentuk pemulihan tugas dan jabatan notaris kembali atau pemberhentian baik hormat atau tidak hormat.

b. Sanksi Perdata

Sanksi yang dijatuhkan kepada seorang Notaris yang melakukan perbuatan melawan hukum pembuatan akta otentik seperti perjanjian nominee atas Putusan Pengadilan adalah sanksi perdata. Dalam hal ini, peran MKN baru terlihat dalam proses peradilan dengan memberikan persetujuan terhadap permintaan persetujuan pemanggilan Notaris untuk hadir dalam penyidikan, penuntutan, dan proses peradilan. Bapak Notaris Ketut Wirata, mengatakan bahwa "Sanksi perdata juga bisa dikenakan ke Notaris yang membuat perjanjian nominee, para pihak bisa minta ganti rugi dari akta yang batal demi hukum atas Putusan Pengadilan."

Sanksi ini berbentuk penggantian biaya, ganti rugi dan bunga merupakan akibat yang diterima Notaris dari tuntutan pihak yang dirugikan karena pembuatan akta oleh Notaris. Penggantian biaya, ganti rugi atau bunga harus berdasarkan hubungan hukum antara Notaris dengan para pihak yang menghadap Notaris. 
c. Sanksi Pidana

Sanksi pidana terhadap Notaris atas akta yang dibuatnya tidak diatur dalam UUJN-P namun tanggung jawab notaris secara pidana dikenakan apabila notaris melakukan perbuatan pidana, seperti pemalsuan tanda tangan disertai pembuatan akta perjanjian nominee dalam kasus Nomor 158/Pdt.G/2015/ PN.DPS. Dalam hal pemberian sanksi pidana kepada Notaris, MKN baru ikut berperan dalam proses peradilan dengan memberikan persetujuan terhadap permintaan persetujuan pemanggilan Notaris untuk hadir dalam penyidikan, penuntutan, dan proses peradilan. Ibu Notaris Nella Hasibuan, mengatakan bahwa "Dalam hal perjanjian nominee, Notaris bisa dikenakan sanksi pidana jika di dalamnya terdapat pemalsuan tanda tangan oleh Notaris."

Sekretaris Majelis Kehormatan Notaris Wilayah Kota Denpasar Ida Bagus Made Danu Kresnawan, mengatakan: "Notaris itu bisa kena sanksi pidana, apabila Notaris itu terbukti yang menganjurkan para pihak untuk membuat perjanjian nominee, karena itu sudah termasuk keterangan palsu, pasal 263, 264 KUHP." Dalam prakteknya ditemukan fakta pelanggaran atas sanksi tersebut kemudian dikategorikan sebagai suatu tindak pidana yang dilakukan oleh Notaris.

\section{Kesimpulan}

Peran Majelis Pengawas Notaris dan Majelis Kehormatan Notaris dalam penyelesaian kasus pelanggaran kode etik notaris terhadap notaris yang membuat akta perjanjian nomine. MKN berperan menyelenggarakan sidang untuk memeriksa Notaris dan pemberian sanksi administratif dan MPN melakukan pemeriksaan terhadap permohonan yang diajukan oleh penyidik, penuntut umum, dan hakim; serta memberikan persetujuan atau penolakan terhadap permintaan persetujuan pemanggilan Notaris untuk hadir dalam seluruh proses hukum. Bentuk sanksi yang diberikan oleh,
Majelis Pengawas Notaris dan Majelis Kehormatan Notaris terhadap notaris yang membuat akta perjanjian nominee dapat berupa sanksi administrasi yaitu peringatan lisan, peringatan tertulis, pemberhentian sementara, pemberhentian dengan hormat dan pemberhentian dengan tidak hormat, sanksi perdata berupa penggantian biaya, ganti rugi dan bunga merupakan akibat yang akan diterima Notaris atas tuntutan para penghadap yang merasa dirugikan atas pembuatan akta oleh Notaris, selain itu juga dapat dijatuhi sanksi pidana apabila Notaris melakukan perbuatan seperti pemalsuan tanda tangan disertai pembuatan akta perjanjian nominee.

\section{Saran}

Peran MPN dan MKN terhadap penyelesaian kasus pelanggaran kode etik Notaris terhadap Notaris yang membuat akta perjanjian nominee belum maksimal, disarankan kedua lembaga untuk lebih aktif lagi dalam menanggulangi kasus perjanjian nominee ini serta perlu adanya kesadaran dari Para Pihak dan Notaris itu sendiri untuk tetap menjaga keluhuran jabatan Notaris. Sanksi yang diterapkan MPN dan MKN terhadap Notaris yang membuat akta perjanjian nominee hanya terkesan "seadanya" dan tidak menimbulkan efek jera, disarankan memang perlu untuk dibuatkan peraturan khusus mengenai perjanjian nominee beserta sanksinya agar para pihak dan Notaris benar-benar mematuhi aturan yang berlaku di Indonesia.

\section{DAFTAR PUSTAKA}

Kitab Undang-Undang Hukum Perdata.

Peraturan Menteri Hukum dan Hak Asasi Manusia Republik Indonesia Nomor 7 tahun 2016 tentang Majelis Kehormatan Notaris.

Prajitno, Andi., 2010, Pengetahuan Praktis Tentang Apa dan Siapa Notaris di Indonesia, Surabaya.

Putusan No.787/Pdt.G/2014/PN.DPS. 


\section{Jurnal Cakrawala Hukum}

Vol.8, No.2 Desember 2017: 181-190

Soekanto, Soejono., 1982, Pengantar Penelitian Hukum, Jakarta.

Sumardjono, Maria S.W., 2012, Penguasaan Tanah Oleh Warga Negara Asing Melalui Perjanjian Nominee, Rapat Kerja Wilayah Ikatan Notaris Indonesia (INI) Pengurus Wilayah Bali dan NTT, Denpasar.

Undang-Undang Dasar Negara Republik Indonesia Tahun 1945.

Undang-Undang Republik Indonesia Nomor 2 tahun 2014 Tentang Perubahan atas Undang-Undang Nomor 30 Tahun 2004 Tentang Jabatan Notaris.

Undang-Undang Republik Indonesia Nomor 30 Tahun 2004 tentang Jabatan Notaris.

Undang-Undang Republik Indonesia Nomor 5 tahun
1960 tentang Peraturan Dasar Pokok-Pokok Agraria.

Waluyo, Bambang., 2002, Penelitian Hukum Dalam Praktek, Sinar Grafika, Jakarta.

Wisnuwardhani, D. 2017. Implementasi Hak Pekerja Dalam Hal Upah Di Kantor Notaris. Jurnal Cakrawala Hukum, 8(1), 33-43. doi:10.26905/ idjch.v8i1.1728

\section{How to cite:}

Wikantha, A. A. B. M. 2017. Peran Majelis Pengawas dan Kehormatan Terhadap Notaris yang Membuat Akta Perjanjian Nominee. Jurnal Cakrawalah Hukum, 8(2). 